\title{
Examining the Effects of Technology Attributes on Learning: A Contingency Perspective
}

\author{
Jennifer Nicholson and \\ Darren Nicholson \\ Rowan University, \\ Glassboro, NJ, USA
}

\author{
nicholsonj@rowan.edu; \\ nicholson@rowan.edu
}

\author{
Joseph S. Valacich \\ Washington State \\ University, \\ Pullman, WA, USA
}

jsv@wsu.edu

\section{Executive Summary}

In today's knowledge economy, technology is utilized more than ever to deliver instructional material to the learner. Nonetheless, information may not always be presented in a manner that maximizes the learning experience, resulting in a negative impact on learning outcomes. Drawing on the Task-Technology Fit model, a research framework was developed to investigate the influence of vividness, interactivity, task complexity, and learning style on performance, sat isfaction, interest, and perceived mental effort in the context of learning how to use an office productivity tool via a computer-mediated learning environment.

It was hypothesized that vividness and interactivity would increase satisfaction and interest and that the affects of vividness and interactivity on performance and perceived mental effort would vary depending on the complexity of the task. It was also hypothesized that vividness and learning style would interact to influence performance and perceived mental effort when a task was more complex. A laboratory experiment was employed to test the research model. The experiment manipulated two levels of vividness, interactivity, and task complexity, result ing in six unique treatment conditions. In each of these treatment conditions, subjects viewed a computerbased tutorial on how to complete a task using a specifictool in Microsoft Excel. Subjects were then asked to complete a similar task using this same Excel tool.

Overall, strong support was found in support of the hypotheses. Findings indicate that presenting information in a more vivid or more interactive learning environment will significantly increase satisfaction with the learning environment as well as interest in the topic. Furthermore, strong support was found for utilizing a more vivid or more interactive presentation to increase performance and reduce perceived mental effort when a task is more complex. Mixed support was found

Material published as part of this publication, either on-line or in print, is copyrighted by the Informing Science Institute. Permission to make digital or paper copy ofpart or all of these works for personal or classroomuse is granted without fee provided that the copies are not made or distributed for profit or commercial advantage AND that copies 1) bear this notice in full and 2) give the full citation on the first page. It is permissible to abstract these works so long as credit is given. To copy in all other cases orto republish or to post on a serveror to redistribute to lists requires specific permission and payment of a fee. Contact 0HPublisher@Informing Science.org to request redistribution permission. regarding the influence of vividness and learning style on performance and perceived mental effort for a more complex task.

This research contributes to our theoretical understanding of instructional design and the influence of technology characteristics on learning outcomes. These findings also serve to guide those who design and disseminate information in computer-mediated contexts. More-

Editor: Paul Jerry

An earlier version of this paper was presented at the AIS SIG-ED IAIM 2007 Conference 
over, multimedia production is both expensive and time consuming and, as this study indicates, may not always enhance learning out comes.

Keywords: computer-mediated learning, task complexity, vividness, interact ivity, learning style, task-technology fit

\section{Introduction}

Today's economy is characterized by industrial change, globalization, increased intensive competition, knowledge sharing and transfer, and a revolution in information technology (Zhang \& Nunamaker, 2003). In order to succeed in such an economy, one must commit to a regimen of lifelong learning. This insatiable demand for continuous knowledge has resulted in a dramatic increase in the utilization of technology as an educational tool with which to convey information to the learner, a trend that can be witnessed in both institutions of higher education as well as the corporate world.

Business schools are increasingly viewing technology-mediated educational programs as a key resource in differentiating themselves from other schools and in gaining a compet it ive advantage (Alavi \& Gallupe, 2003). On the corporate front, organizations view learning as important as positive cash flow in order to survive in today's global market (Chen, Lee, Zhang, \& Zhang, 2003) and are using technology as a critical training aid in helping employees improve their skills and knowledge. In a 2006 survey of the corporate learning market, Bersin \& Associates (2007) report that the average annual budget increase for corporate learning is expected to increase by $7 \%$ and that $60 \%$ of the over 1400 respondents use virtual classroom technologies.

This demand for technology-delivered education from both higher education institutions and corporate America has sparked a great deal of interest in the design and application of technologydelivered education (Alavi \& Gallupe, 2003). Prior research investigat ing technology-delivered education can be classified into two general cat egories - technology-mediated learning (TML) research and multimedia research. The first cat egory, technology-mediated learning, has been defined as "a learning experiencethat is significantly moderated through the use of information and communication technology" (Alavi \& Gallupe, 2003). TML research has essentially focused on comparing traditional, or non-supported, classrooms to virtual, or technology-supported, classrooms (e.g., Alavi, Wheeler, \& Valacich, 1995; Piccoli, Ahmad, \& Ives, 2001) or on examining the presence or absence of a technology on learning outcomes (e.g., Alavi, 1994; Leidner \& Fuller, 1997; Leidner \& Jarvenpaa, 1993). Prior research, however, has fallen short as it has failed to examine what feat ures or attributes of a technology will enhance the learning process or investigate the effects of information characteristics, such as task complexity, that might influence learning outcomes.

The second category of research in this area examines the use of multimedia on learning outcomes. While very similar to technology-mediated learning research, there is a subtle difference. In TML studies, the word technology usually refers to the medium through which the information is being communicated (e.g., computer, TV). Multimedia research, however, views technology as the collection of tools used to deliver information to an individual (Piccoli et al., 2001). Examples of delivery technologies in this cont ext include text, hypertext, graphics, streaming audio and video, computer animations and simulations, embedded tests, and dynamic content (P iccoli et al., 2001). Only a handful of studies examining the impact of multimedia on learning have been conducted in the Information Systems discipline. Some of these studies found that interactive multimedia environments (i.e., control over features of the presentation) positively influenced user att it udes (e.g., Haseman, Polatoglu, \& Ramamurthy, 2002; Kettanurak, Ramamurthy, \& Haseman, 2001) and that information complexity interacted with the multimedia environment to influence learning outcomes (Andres, 2004). There exists very little research, however, that has 
been conducted with the goal of building theoretical guidance for development of effective multimedia systems (Lim, O'Connor, \& Remus, 2005). In sum, prior research has shown mixed results for the effectiveness of utilizing multimedia technology in a learning environment.

This research specifically examines computer-mediated learning, that is, what aspects of a computer-mediated learning environment have the great est influence on improving learning outcomes. It is believed that several factors contribute to the effect iveness of a computer-mediated learning experience. These include characteristics of the technology used to convey the instructional material (e.g., Clark, 1983; Eveland, 2003), characteristics of the task it self, and characteristics of the leamer (e.g., Alavi \& Leidner, 2001; Goodhue, Klein, \& March, 2000; Steuer, 1992). While several studies have examined the effects of technology on learning, very few have investigated the interplay between these factors. Drawing on the Task-Technology Fit model, a research model is developed to investigate the impact of task, technology, and individual characteristics on various learning outcomes. The study specifically examines the influence of vividness, interactivity, task complexity, and leaming style on learning outcomes in the context of learning procedural knowledge.

\section{Review of Theoretical Foundations}

What follows is a discussion of Paivio's Dual Coding Theory (DCT) (1971), which provides a detailed, theoretical explanation for using media characteristics to increase retention and retrieval. This includes a brief discussion of Cognitive Load Theory (CLT) (Sweller, 1988, 1989, 1994), a slightly different yet supporting theoretical perspective. A discussion as to the importance of mental models in leaming, as well as the role that media characteristics can play in mental model formation, is then provided. Finally, theories associated with learner control are addressed.

\section{Dual Coding Theory and Cognitive Load Theory}

Dual coding theory (Paivio, 1971, 1986) posits that learners can build both visual and verbal modes of mental representation as well as connections between them. In other words, humans possess two distinct information processing systems - one that represents information verbally and one that represents information visually. If learners are presented with only verbal or only visual information, memory capacity seems to be greater for the visual information (Anderson, 2000). Nonetheless, the theory predicts that leamers will remember and transfer material better if they encode the material both visually and verbally because they have two separate ways of finding the information in memory. However, according to cognitive load theory (Chandler \& Sweller, 1991; Sweller, 1988, 1989, 1994; Sweller \& Chandler, 1994), caution must be taken when designing and organizing instructional material that includes both visual and verbal elements so as not to create an extraneous cognitive load.

\section{Mental Models}

Learning has been broadly defined as changes that occur in an individual's mental models (Shuell, 1986) or, more specifically, the process of constructing, extending, and refining mental models (Alavi, 1994). The term mental model oft en refers to internal represent at ions of a real or imagined situation that can be "run" by an individual when trying to solve problems, understand a system, or predict events (e.g., Alessi \& Trollip, 2001; Johnson-Laird, 1983; McKellar, 1957; Miller, 1979). Having a well-developed mental model of a concept will aid learners in further understanding of the concept as well as dictate their subsequent level of performance in demonstrat ing their knowledge of the concept (Wilson \& Rutherford, 1989).

While it is generally accepted that mental models are critical to the development of knowledge and expertise (e.g., Frederiksen, White, \& Gutwill, 1999), there is always a risk that an individual 
may not develop a correct mental model. A particular method that can be used to aid learners in the development of proper mental models is to provide conceptual models (Hagmann, Mayer, \& Nenniger, 1998). While a mental model exists in the learner's mind, conceptual models are devices that can be incorporated into instructional material through the use of different media such as animations, diagrams, and video presentations.

\section{Learner Control}

Learner control is believed to be an essential part of effective learning (Lawless \& Brown, 1997). According to Kettanurak et al., (2001), learner control is most closely aligned with the tenants of behaviorist theory, which emphasizes learning through reinforcement. Learner control allows for repeatability; the more information is repeated, the better and longer it is remembered (Alessi \& Trollip, 1991). Theorists and empirical researchers have also suggested that some degree of learner control can lead to greater intrinsic interest in an activity and satisfaction with the learning experience, which ultimately leads to improved academic performance (Kinzie, Sullivan, \& Berdel, 1988; Lepper, 1985; Merrill, 1983, 1994; Williams, 1996). Additionally, learner control can avoid overloading the learners' working memory (Rieber, 1994) as they can movethrough the information at a rate and sequence that is comfortable for them.

In summary, based on the aforementioned theories, a computer-mediated learning environment should utilize multimedia to appeal to multiple sensory channels as well as provide more opportunities for active learning to aid the learner in constructing an accurate mental model without producing an extraneous cognitive load. Information Systems researchers, however, caution that the capabilities offered by multimedia only provide an opport unity to generate benefits rather than guarantee them (Lim, Benbasat, \& Ward, 2000). Multimedia production is an expensive, time-consuming endeavor not to be taken lightly; hence, it is essentialto determine whether or not its advantages exist and under what conditions it is beneficial to invest in multimedia technology (Lim \& Benbasat, 2002).

\section{Research Framework and Hypotheses Development}

This research draws on the Task-Technology Fit Model (Goodhue, 1995) to investigate the impacts oftask, technology, and individual characteristics on various learning out comes. The TaskTechnology Fit framework proposes that the better the fit between task requirements, technology functionalities, and individual abilities, the better performance will be. Thetask-technology fit framework has been integrated into a number of studies (e.g., Dishaw \& Strong, 1999; D'Ambra \& Rice, 2001), which have found support for the primary notion of TTF - that in order for a technology to positively impact performance it must be designed in a way that supports task requirements and individual abilities.

In this study, we examine the impact of task, technology, and individual characteristics on several different learning outcomes that are believed to be essential elements in any learning event. These include performance, interest, satisfaction, and perceived mental effort. Measuring an individual's performance gives us an immediate indication that the desired learning has occurred and helps us in determining whether the instructional material has met its design objectives (Gagne, Briggs, \& Wager, 1992). Leamer satisfaction is an important outcome of a good leaming experience and has been employed in both an academic and a business setting to evaluate the effectiveness of learning environments (e.g., Alavi et al., 1995; Piccoli et al., 2001). Furthermore, research has shown a substantial effect between a learner's interest in a topic and their level of achievement (Renninger, Hidi, \& Krapp, 1992). Perceived mental effort is also included as a learning outcome in this study in order to gain insight in to the amount of cognitive effort that is expended when performing a task. Mental effort refers to the amount of capacity that an individ- 
ual allocates to meet instructional demands and is considered to be an indicat or of cognitive load (Paas, 1992).

A detailed research model of the relationships under investigation in the current study is presented in Figure 1. Specific hypotheses regarding the influence of technology characteristics on learning outcomes, as well as interactions between technology, task, and individual characteristics are presented below.

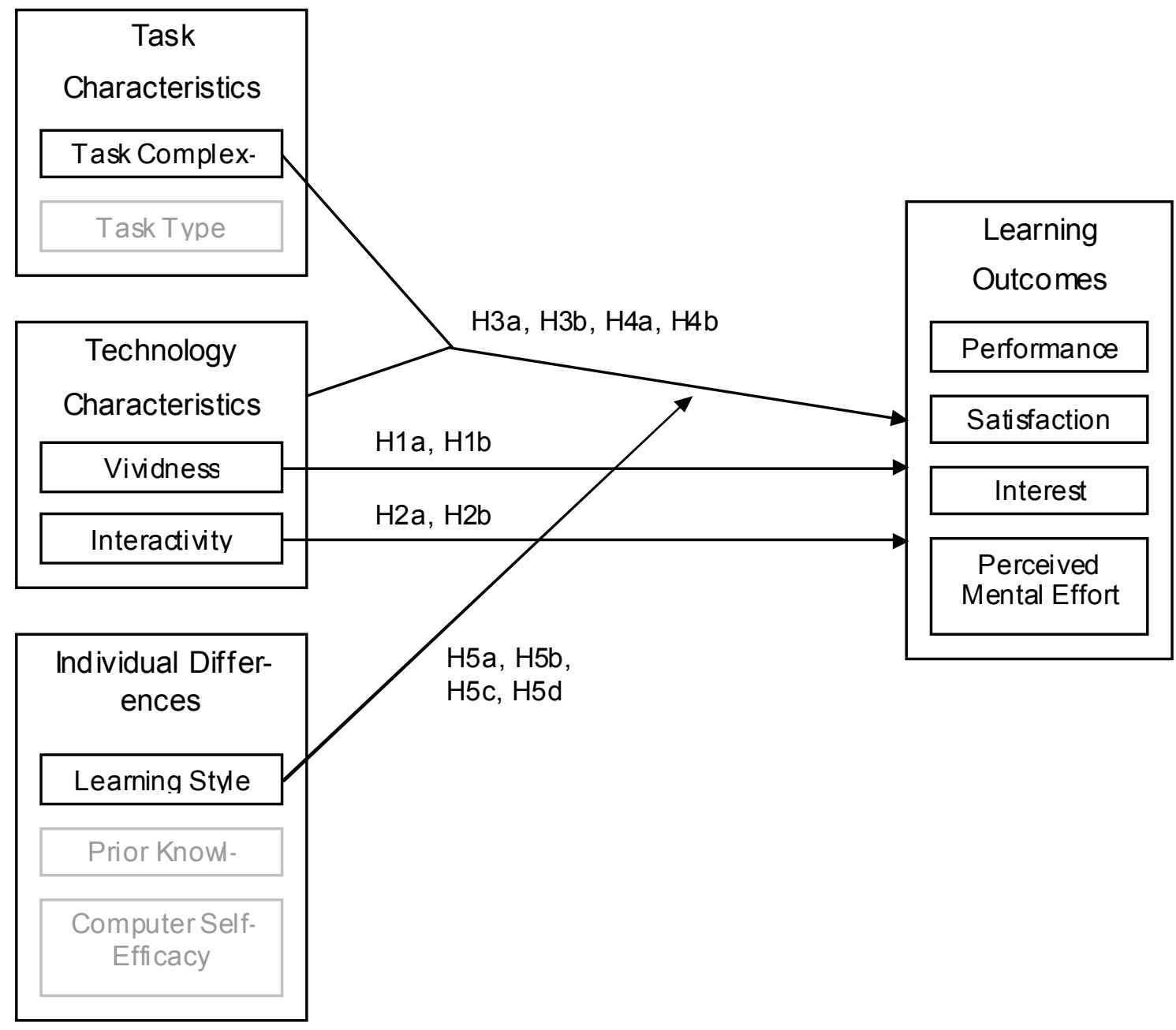

Figu re 1: Research Model

(Note: Variables in gray boxes were controlled for in this study)

\section{Technology Characteristics}

Technology characteristics can enhance or inhibit efficient delivery of instructional material (Alavi \& Leidner, 2001) and thus may play a crucial role in influencing the learning process (Kozma, 1991). The two technology characteristics under investigation in the current study are vividness and interactivity.

Vividness has been defined as "the representational richness of a mediated environment as defined by its formal features; that is, the way in which an environment presents information to the 
senses" (Steuer, 1992, pp. 81). A presentation that utilizes multiple modalities to appeal to a number of senses (e.g., animation and narration) serves to further enhance vividness. A presentation media that contains a high level of sensory stimulation and appeal is associated with increased sustained attention (Agius \& Angelides, 1999; Syed, 2001). Attention has been shown to be related to interest, learning, motivation, and satisfaction (Alessi \& Trollip, 1991; Andres, 2004; Keller \& Suzuki, 1988; Webster \& Hackley, 1997). A vivid presentation is also believed to require less cognitive effort to process, as the meaning can be directly inferred and does not require one to extrapolate meaning artificially (Lim, 1996). Thus, the following main effects of vividness are hypothesized:

H1 a: A more vivid presentation will increase satisfaction.

H1b: A more vivid presentation will increase interest.

Interactivity can be described as the extent to which the leamer has control over some aspect of the learning environment. Environments with a relatively low degree of interactivity are presumed to be less successful at engaging and immersing learners (Zazelenchuk, 1997). The two feat ures of interactivity that are investigated most often in a learning environment are pace and sequencing (Haseman et al., 2002; Kettanurak et al., 2001). These feat ures are considered to be very low, however, in the realm of possible interactivity features that offer users some kind of control (Kristof \& Satran, 1995). The level of interactivity can be increased by adding another feature of interactivity proposed by Haseman et al. (2002) - practice. Providing an element of practice is believed to aid in the efficient transfer and retention of knowledge to user's short-term as well as long-term memory. The importance of practice in learning is stressed in a number of learning strat egies, including learning-by-doing, active learning, and hands-on leaming.

Similar to vividness, a high level of interactivity aids in focusing and engaging attent ion (Alessi \& Trollip, 2001; Heinich, Molenda, \& Russell, 1989). Additionally, high levels of interact ivity have been shown to positively influence user attitudes, such as motivation (Kettanurak et al, 2001). It has also been suggested that interactivity can increase one's intrinsic interest in an activity as well as one's satisfaction with the learning experience (Kinzie et al., 1988; Lepper, 1985; Mitchell, 1993). Thus, the following main effects of interact ivity are hypothesized:

H2a: A more interactive presentation will increase satisfaction.

H2b: A more interactive presentation will increase interest.

While it has been posited that vividness and interactivity will result in an overall increase in satisfaction and interest, it is believed they have a more complex relationship with performance and perceived mental effort. Specifically, it is thought that the influence of vividness and interactivity on these out comes will vary depending on characteristics of the task and the individual.

\section{Technology and Task Characteristics}

It has been suggested that the impact of using different technology characteristics to represent data may depend on characteristics of the task (T an \& Benbasat, 1990; Tract insky \& Meyer, 1999). Several different task characteristics have been purported to effect performancethrough their influence on cognitive processes; however, task complexity is said to be the most frequently studied and operationalized construct in information systems research (Zigurs \& Buckland, 1998) and has been shown to be an import ant variable in models of computertraining (Bolt, Killough, \& Koh, 2001).

Performance of a more complex task requires the learner to generate a more elaborate mental model (White \& Frederiksen, 1990). Hence, tasks that are more complex are associated with an increase in cognitive load, which can reduce performance and learning (Bannert, 2002; Sweller, 
vanMerrienboer, \& Paas, 1998). Imagery is an inherent component of mental model formation (Sadoski \& Paivio, 2001). Visual images act to simplify complex information and help to provide an individual with a concrete and accurate mental image of the instructional material, decreasing cognitive load and increasing performance.

Thus, when learning a task that is more complex, a more vivid presentation should be superior to a less vivid presentation. Thus, the following interactions bet ween vividness and task complexity are hypothesized:

H3a: Performance will be higher fortasks that are more complex when vividness is high than when vividness is low.

H3b: Perceived mental effort will be lower for tasks that are more complex when vividness is high than when vividness is low.

Providing the leamer with a higher level of interactivity captures the learner's attention and increases a user's engagement with the task environment (Alessi \& Trollip, 2001; Heinich et al, 1989). This leads to deeper processing of the information, resulting in a better command of the information (Brown, Collins, \& Duguid, 1989; Merrill, 1975; Wittrock, 1978), as well as aiding the individual in forming a personal mental model of the task (Wild, 1996). As mentioned above, a more complex task requires the formation of a more elaborate mental model, which may place a greater cognitive load on the learner. A learning environment with a high level of interactivity can aid in mental model creation, thereby reducing cognitive load and increasing performance.

Thus, when learning a task that is more complex, a more interactive presentation should be superior to a less interactive presentation. Thus, the following interactions between interactivity and task complexity are hypothesized:

H4a: Performance will be higher fortasks that are more complex when interactivity is high than when interactivity is low.

H4b: Perceived mental effort will be lower for tasks that are more complex when interactivity is high than when interactivity is low.

\section{Technology, Task, and Individual Characteristics}

Prior research has suggested that learning style is a crucial learner variable, as it may offerthe clearest indication of how best to tailor technology to meet the needs of specific learner populations (Dillon \& Gabbard, 1998). Providing instruction in a manner consistent with an individual's preferred processing style may reduce extraneous cognitive load and enhance learning (Pillay, 1998). While the term learning style has come to mean many things to many people, the current research defines learning style as an individual's inclination to process visual information (pictures) as opposed to verbal information (text) (Childers, Houston, \& Heckler, 1985). Although it is possible that an individual can make use of alternative styles if forced to (Riding \& Dyer, 1980), the effort required to do so may place a burden on the individual's cognitive capacity and impair learning (Sweller, 1989).

When a task is more complex, and therefore already associated with an increase in cognitive load, those individuals that do not have to place an extra burden on their cognitive capacity by trying to make use of an alternative learning style should perform better. When a task is less complex it demands very little of one's working memory, hence there is more cognitive capacity available to devote to making use of an alternative learning style. As such, the impact that leaming style is expected to have on performance and perceived mental effort under different levels of vividness is only expected to be significant ifthe task is more complex. Thus, the following interactions between vividness, task complexity, and learning style are hypothesized: 
H5a: Verbal processors will perform better than visual processors when a task is more complex and vividness is low.

H5b: Perceived mental effort will be lower for verbal processors than visual processors when a task is more complex and vividness is low.

H5c: Visual processors will perform better than verbal processors when a task is more complex and vividness is high.

H5d: Perceived mental effort will be lower for visual processors than verbal processors when a task is more complex and vividness is high.

\section{Research Method}

\section{Research Design}

A laboratory experiment was employed forthis investigation. The experiment manipulated two levels of each factor - vividness, interactivity, and task complexity - resulting in a betweensubjects design. The design thus yielded six treatment conditions (see Table 1). Treatment 1 was used to examine the influence of either vividness or interactivity in the low complexity condition, while treatment 4 was used to examine the influence of either vividness or interactivity in the high complexity condition.

Table 1: Sample Size, Means and Standard De viations by Tre atment

\begin{tabular}{|c|c|c|c|c|c|c|}
\hline Cell & 1 & 2 & 3 & 4 & 5 & 6 \\
\hline Treatment & $\overline{\mathrm{LC} / \mathrm{LV} / \mathrm{LI}}$ & $\mathrm{LC} / \mathrm{HV} / \mathrm{LI}$ & $\mathrm{LC} / \mathrm{LV} / \mathrm{HI}$ & $\mathrm{HC} / \mathrm{LV} / \mathrm{LI}$ & $\mathrm{HC} / \mathrm{HV} / \mathrm{LI}$ & $\mathrm{HC} / \mathrm{LV} / \mathrm{HI}$ \\
\hline $\mathbf{N}$ & 45 & 44 & 46 & 41 & 40 & 44 \\
\hline & & & & & & \\
\hline \multicolumn{7}{|l|}{ Control Variables } \\
\hline \multicolumn{7}{|l|}{ Prior Knowedge } \\
\hline Excel & $\begin{array}{l}\mathrm{M}=4.33 \\
\mathrm{SD}=.83\end{array}$ & $\begin{array}{l}M=4.43 \\
\mathrm{SD}=1.18\end{array}$ & $\begin{array}{l}\mathrm{M}=4.23 \\
\mathrm{SD}=.98\end{array}$ & $\begin{array}{l}M=4.46 \\
S D=.96\end{array}$ & $\begin{array}{l}M=4.30 \\
S D=.94\end{array}$ & $\begin{array}{l}M=4.39 \\
S D=.98\end{array}$ \\
\hline Solver & & & & $\begin{array}{l}M=1.67 \\
S D=.91\end{array}$ & $\begin{array}{l}M=1.85 \\
S D=1.05\end{array}$ & $\begin{array}{l}M=1.68 \\
S D=1.21\end{array}$ \\
\hline AutoFilter ${ }^{\star}$ & $\begin{array}{l}M=1.96 \\
S D=1.20\end{array}$ & $\begin{array}{l}M=2.33 \\
S D=1.18\end{array}$ & $\begin{array}{l}M=2.14 \\
S D=1.20\end{array}$ & & & \\
\hline $\begin{array}{l}\text { Computer } \\
\text { Self-Efficacy }\end{array}$ & $\begin{array}{l}M=5.85 \\
S D=1.91\end{array}$ & $\begin{array}{l}M=6.71 \\
S D=1.65\end{array}$ & $\begin{array}{c}M=5.36 \\
S D=1.88\end{array}$ & $\begin{array}{l}M=5.90 \\
S D=1.89\end{array}$ & $\begin{array}{c}M=5.92 \\
S D=1.92\end{array}$ & $\begin{array}{l}M=5.60 \\
S D=1.87\end{array}$ \\
\hline Prior Interest & $\begin{array}{l}M=3.90 \\
\mathrm{SD}=1.03\end{array}$ & $\begin{array}{c}M=3.71 \\
S D=1.46\end{array}$ & $\begin{array}{l}M=3.95 \\
S D=1.34\end{array}$ & $\begin{array}{l}M=4.15 \\
S D=1.28\end{array}$ & $\begin{array}{l}M=3.99 \\
S D=1.46\end{array}$ & $\begin{array}{c}M=3.82 \\
S D=1.14\end{array}$ \\
\hline \multicolumn{7}{|l|}{ Independent Variable } \\
\hline Learning Style & $\begin{array}{l}M=2.72 \\
\mathrm{SD}=.32\end{array}$ & $\begin{array}{l}M=2.70 \\
S D=.32\end{array}$ & $\begin{array}{l}M=2.59 \\
S D=.34\end{array}$ & $\begin{array}{l}M=2.71 \\
S D=.28\end{array}$ & $\begin{array}{l}M=2.65 \\
\mathrm{SD}=.38\end{array}$ & $\begin{array}{l}M=2.72 \\
S D=.32\end{array}$ \\
\hline \multicolumn{7}{|l|}{ Dependent Variables } \\
\hline Performanœ & $\begin{array}{l}M=4.27 \\
S D=1.47\end{array}$ & $\begin{array}{l}M=4.64 \\
S D=1.12\end{array}$ & $\begin{array}{l}\mathrm{M}=4.96 \\
\mathrm{SD}=.30\end{array}$ & $\begin{array}{l}M=1.12 \\
S D=2.09\end{array}$ & $\begin{array}{l}M=4.82 \\
S D=3.17\end{array}$ & $\begin{array}{l}M=4.61 \\
S D=3.36\end{array}$ \\
\hline Satisfaction & $\begin{array}{l}M=3.88 \\
\mathrm{SD}=1.66\end{array}$ & $\begin{array}{l}\mathrm{M}=5.82 \\
\mathrm{SD}=.88\end{array}$ & $\begin{array}{c}M=5.72 \\
S D=1.08\end{array}$ & $\begin{array}{l}M=3.72 \\
\mathrm{SD}=2.00\end{array}$ & $\begin{array}{l}M=4.94 \\
\mathrm{SD}=1.50\end{array}$ & $\begin{array}{l}\mathrm{M}=4.86 \\
\mathrm{SD}=1.40\end{array}$ \\
\hline Interest & $\begin{array}{l}M=3.19 \\
S D=1.23\end{array}$ & $\begin{array}{l}M=4.52 \\
S D=1.21\end{array}$ & $\begin{array}{l}M=4.37 \\
S D=1.29\end{array}$ & $\begin{array}{l}M=3.02 \\
S D=1.66\end{array}$ & $\begin{array}{l}M=4.14 \\
S D=1.31\end{array}$ & $\begin{array}{l}M=3.50 \\
S D=1.38\end{array}$ \\
\hline $\begin{array}{l}\text { Perceived Mental } \\
\text { Effort }\end{array}$ & $\begin{array}{l}M=3.00 \\
S D=1.69\end{array}$ & $\begin{array}{l}M=1.33 \\
S D=.71\end{array}$ & $\begin{array}{l}M=1.33 \\
S D=.65\end{array}$ & $\begin{array}{l}M=6.35 \\
S D=.88\end{array}$ & $\begin{array}{l}M=4.06 \\
S D=1.80\end{array}$ & $\begin{array}{l}M=4.30 \\
\mathrm{SD}=1.83\end{array}$ \\
\hline
\end{tabular}


*Prior knowledge of Solver was only measured in the more complex treatment conditions, and prior knowledge of AutoFilter was only measured in the less complex treatment conditions.

Key: LC = Low Complexity; LV = Low Vividness; LI = Low Interactivity; HC = High Complexity; HV = High Vividness; $\mathrm{HI}=$ High Interactivity

Extensive pilot testing was conducted to address the validity of the research design and operationalizations of the variables under investigation (see Nicholson, 2006). Interactivity was held constant across the treatments that examined the effects of vividness, while vividness was held constant across the treatments that investigated the effects of interactivity. Task type was held const ant across treatment conditions; all treatments involved a procedural-type task. The following variables were additionally controlled for in this study: prior knowledge, computer selfefficacy, and pre-treatment interest. The means and standard deviations for all variables across all treatment conditions are presented in Table 1.

Since subjects were randomly assigned to treatments, additional analyses were conducted to insure that there were no significant differences among subjects between the treatments on the independent and control variables. A one-way analysis of variance revealed no significant difference between treatment conditions on prior knowledge of Excel, Solver, or Aut oFilter, preinterest in the topic, or on learning style. There was a significant difference between treatment conditions on computer self-efficacy; hence a Tukey's HSD was conducted as a follow-up test. This revealed a significant difference between cells 2 and 3 and cells 2 and 6 . It was concluded that this had no impact on the investigation since hypothesis testing never called for a direct comparison between cells 2 and 3 or between cells 2 and 6 .

\section{Subjects}

A total of 260 subjects were recruited from a North American university campus and randomly assigned to one of the six treatment conditions. The average age of participants was 22.08 years. Of the 260 subjects, 121 (46.5\%) were female and 139 (53.5\%) were male. In order to assess random assignment, background dat a was collected and ANOVAs were conducted on age, GPA, and level of computer experience, while a chi-square test was conducted on gender. The results showed no significant difference between the treatment conditions on any of these variables; hence no follow-up tests were conducted.

\section{Factors Investigated}

\section{Task Complexity}

Task complexity can be objectively defined and determined independently of the particular individual performing the task (Campbell, 1988; Wood, 1986). According to Wood (1986), increases in the component complexity of a task occur when there are more information cues to process, more acts to execute, or increased interdependence between the cues and acts. The research design contrasted two levels of task complexity - low complexity and high complexity. Both tasks used in this study were Exceltasks. The more complex task was adopted from a study conducted by Bolt et al., (2001) and required the use of Solver in Excel. The less complex task for the current study required the use of a custom Auto Filter in Excel. The component complexity of each of these tasks was decomposed for the current study (see Nicholson, 2006).

A manipulation check was not performed on task complexity; rather, perceived mental effort was used as a proxy for measuring the perceived complexity of the task. The manipulation check revealed a significant difference between complexity treatments $(\mathrm{t}(258)=-14.92, \underline{p}=.000)$ on perceived mental effort. In other words, those subjects in the more complex condition perceived the task to require much more mental effort than those subjects in the less complex condition. 


\section{Vividness and interactivity}

The research design contrasted two levels of vividness - low and high. The more vivid presentation included text, animation, and narration of the text; while the less vivid presentation consisted only of text. The research design also contrasted two levels of interactivity - low and high. As previously mentioned, providing learners with control over the pace and sequencing of instructional material is at the low end of the interactivity spectrum (Krist of \& Satran, 1995). Thus, the low interactivity condition only allowed subjects control over the pace and sequencing of the presentation. In addition to allowing individuals to control the pace and sequencing of the presentation, the high interactivity condition also allowed subjects to practice each step of the task after it was presented.

A manipulation check was conducted on both vividness and interact ivity. An independent samples t-test revealed a significant difference $(\mathrm{t}(168)=-34.408, \underline{\mathrm{p}}=.000)$ bet ween vividness treatments as well as a significant difference between interactivity treatments $(\mathrm{t}(174)=-55.43, \underline{\mathrm{p}}=$ .000 ), indicating the manipulation of those factors was successful.

\section{Learning style}

The Style of Processing (SOP) scale, created by Childers et al. (1985), was adapted for examining learning styles in the context of the current study. The SOP scale hinges on the notion that individuals have a preference for processing information that leads them to select one strat egy of information processing over another (visual vs. verbal) (Childers et al., 1985). The response format for the SOP scale consists of a 4-point Likert-type scale anchored by 1 (Always True) and 4 (Always False). When items have been appropriately reverse coded, a low score on the SOP scale indicates a preference for verbal processing while a high score indicates a preference for visual processing. Relying on the SOP scale, leaming style is thus defined as an individual's preference and propensity to engage in a verbal as opposed to visual modality of processing.

The SOP scale has exhibited fairly high reliability in prior studies, with a coefficient alpha ranging from .67 to .88 (Childers et al., 1985; Sojka \& Giese, 2001). The original SOP scale was administered during the pilot testing phase of the current study, which resulted in a reduced scale with a coefficient alpha of .72 for the visual subscale and .80 for the verbal subscale. In order to examine hypothesis $5 \mathrm{a}-5 \mathrm{~d}$ a median split was performed on style of processing by treatment, which allowed SOP to be treated as a categorical variable.

\section{Learning outcomes}

The study measured both objective and subjective dependent variables. The objective measure was performance, while the subjective measures included satisfaction, interest, and perceived mental effort. Each task was decomposed into a number of steps that must be performed correctly in order to generate an accurate solution. The dependent variable, performance, was thus operationalized as the total number of steps that were performed correctly. Satisfaction was assessed with an instrument adapted from Doll and Torkzadeh (1988), and Rai, Lang, and Welker, (2002). Interest was assessed using a que stionnaire adapted from the Intrinsic Motivation Inventory (IMI) and Davis, Bagozzi, and Warshaw (1992).

An instrument to measure perceived mental effort was developed specifically for the current study. The scale that emerged from the instrument development process consisted of 13 items and had a coefficient alpha of 97 . The scale was subjected to additional pilot testing on two different occasions, resulting in a coefficient alpha of .98 and .99 . Due to experimental time constraints, the assessment instrument was reduced to a 4-item scale. This was done by conducting a principal components factor analysis with varimax rotation on the original 13 it ems. The three 
Nicholson, Nicholson, \& Valacich

items that had the highest factor loadings, as well as one item that required reverse coding, were retained, resulting in a 4 -item scale.

\section{Procedure}

Subjects entered the computer lab at their designated class time and were asked to login to their computer. Subjects were then provided with an overview of the purpose of the study and were told that they would be asked to fill out a series of questionnaires, view a tutorial, and perform a task. If the particular session called for the use of Solver, subjects were then walked through the procedure of adding the Solver tool in Excel. Students were then asked to register with Net Support, a software toolthat enables instructors to teach, monit or, and support students in a networked classroom.

A packet of experimental materials was then provided to each student. Subjects were asked to provide their consent to participate and to fill out the first series of questionnaires: background data, style of processing, prior knowledge, pre-interest in task, and Solver/AutoFilter self-

efficacy. After subjects had completed the first set of questionnaires, one of the six tutorials was provided to them via their PC at which time they were instructed to open and view the presentation. Ifthe treatment involved a high level of vividness, headphones were distributed to subjects prior to viewing the tut orial so that they would be able to hear the narration. If the treatment involved a high level of interactivity, participants were informed prior to viewing the tutorial that they would be required to practice each step of the task in the tut orial as it was being presented and that they would be monitored to make sure that they were in fact practicing the steps (the experimenter monit ored each subject's desktop of their computer via the NetSupport tool to insure that they did in fact practice the steps of the tutorial in Excel). Furthermore, subjects in the high interactivity condition were instructed not to seek help from any source (e.g., a neighbor, the office assistant in Excel, etc.) while practicing the steps in thetutorial. When subjects were done viewing the tutorial, the second set of questionnaires was administered: manipulation check, satisfaction with learning environment, and post-interest in task.

After subjects had completed the second set of questionnaires they were provided with a sheet of task instructions, and an Excel file with preliminary dat a was sent to their computer via Net Support. Subjects were then instructed to use the Excel file sent to their computer and the task instructions to complete a task similar to the one they viewed in the tutorial. Subjects were asked not to employ any Help mechanisms while attempting to perform thetask. Upon completion of the task, the Excel files were collected via Net Support and subjects were given the final questionnaire, perceived mental effort. When subjects had finished complet ing the final questionnaire, they were asked not to share the details of the experiment with anyone out side the class and were thanked for their participation.

\section{Results}

Planned contrasts were used in order to test the hypotheses. Two major advantages of the contrast approach to data analysis are "that it can provide relatively clear and direct evaluations of theoretically-driven predictions" (Furr \& Rosenthal, 2003,p. 48), while at the sametime providing greater statistical power (Rosenthal \& Rosnow, 1985). The results from the hypothesized relationships are provided in Table 2.

In sum, the results supported the hypotheses for a main effect of both vividness and interactivity on satisfaction and interest. The hypothesized interactions between task complex ity and technology characteristics on performance and perceived mental effort were supported as well. Specifically, the findings indicated that when atask is more complex, using a highly vivid present ation or a more interactive presentation to present information will increase performance and decrease 
perceived mental effort. Finally, the results were mixed for hypotheses regarding the effects of vividness, task complexity, and style of processing on performance and perceived mental effort. Results supported the hypothesis that individuals with a preference for visual processing will perform better and perceive the task to require less mental effort than individuals with a preference for verbal processing when the task is more complex and vividness is high. Results did not, however, support similar hypotheses set forth about verbal processors performing better and perceiving the task to require less mental effort than visual processors when the task was more complex and vividness was low.

Table 2: Hypotheses Summary

\begin{tabular}{|l|c|c|c|}
\hline \multicolumn{1}{|c|}{ Hypothesis } & F statistic & p value & Result \\
\hline H1a: A more vivid presentation will increase satisfaction. & 49.77 & .000 & Supported \\
\hline H1b: A more vivid presentation will increase interest. & 34.76 & .000 & Supported \\
\hline $\begin{array}{l}\text { H2a: A more interactive presentation will increase } \\
\text { satisfaction. }\end{array}$ & 46.08 & .000 & Supported \\
\hline $\begin{array}{l}\text { H2b: A more interactive presentation will increase } \\
\text { interest. }\end{array}$ & 15.57 & .000 & Supported \\
\hline $\begin{array}{l}\text { H3a: Perfomance will be higher for tasks that are more } \\
\text { complex when vividness is high than when vividness is } \\
\text { low. }\end{array}$ & 58.60 & .000 & Supported \\
\hline $\begin{array}{l}\text { H3b: Perceived mental effort will be lower for tasks that } \\
\text { are more omplex when vividness is high than when } \\
\text { vividness is low. }\end{array}$ & 57.91 & .000 & Supported \\
\hline $\begin{array}{l}\text { H4a: Perfomance will be higher for tasks that are more } \\
\text { complex when interactivity is high than when interactivity } \\
\text { is low. }\end{array}$ & 54.61 & .000 & Supported \\
\hline $\begin{array}{l}\text { H4b: Perceived mental effort will be lower for tasks that } \\
\text { are more complex when interactivity is high than when } \\
\text { interactivity is low. }\end{array}$ & 48.99 & .000 & Supported \\
\hline $\begin{array}{l}\text { H5a: Verbal processors will perform better than visual } \\
\text { processors when a task is more complex and vividness } \\
\text { is low. }\end{array}$ & 2.53 & .120 & Not \\
\hline $\begin{array}{l}\text { H5b: Perceived mental effort will be lower for verbal } \\
\text { processors than visual processors when a task is more } \\
\text { complex and vividness is low. }\end{array}$ & 0.90 & .348 & Supported \\
\hline $\begin{array}{l}\text { H5c: Visual procssors will perform better than verbal } \\
\text { processors when a task is more complex and vividness } \\
\text { is high. }\end{array}$ & 5.03 & Supported \\
\hline $\begin{array}{l}\text { H5d: Perceived mental effort will be lower for visual } \\
\text { processors than verbal processors when a task is more } \\
\text { complex and vividness is high. }\end{array}$ & 6.15 & .018 & Supported \\
\hline
\end{tabular}


Nicholson, Nicholson, \& Valacich

\section{Discussion}

\section{Technology Characteristics}

A vivid learning environment is one that appeals to multiple senses. It is this sensorially rich mediated environment that is believed to capture the learner's attention, thus leading to increases in learning, interest, and satisfaction (Syed, 2001; Webster \& Hackley, 1997). Prior literature has also shown that a more interactive learning environment can positively influence user attitudes, including increasing one's intrinsic interest in an activity and satisfaction with an activity (Kinzie et al., 1988; Lepper, 1985; Merrill, 1983, 1994; Williams, 1996). In this study, the more vivid and more interactive conditions resulted in an increase in satisfaction and interest. Learner satisfaction is believed to be an important outcome of a good learning experience and can be used to evaluate the effect iveness of learning environments (e.g., Alavi et al., 1995; Piccoli et al., 2001). This is an important finding as well, as prior research has shown a substantial effect between a learner's interest in atopic and their level of achievement (Renninger et al., 1992).

\section{Technology and Task Characteristics}

It is believed that technology characteristics in and of themselves do not lead to an increase in performance or a decrease in perceived mental effort. Rather, as suggested in the literature ( $\mathrm{T}$ an \& Benbasat, 1990; Tractinsky \& Meyer, 1999), it is thought that the impact of using different technology characteristics to represent data depends on characteristics of the task.

Task complexity is an important task characteristic to examine as it has been shown to have detrimental effects on learning and performance. Performance of a more complex task not only requires the learner to generate a more elaborate mental model (White \& Frederiksen, 1990) but it is also accompanied by an increase in cognitive load, which can reduce performance (Bannert, 2002; Sweller et al., 1998). In this study, when the task was more complex, individuals in the more vivid and more interactive conditions performed better and perceived the task to require less mental effort than individuals in the less vivid and less interactive conditions. These results support the notion that an information presentation that utilizes one of two technology characteristics, vividness or interactivity, may aid the learner in mental model formation thereby reducing cognitive load and increasing performance.

\section{Technology, Task, and Individual Characteristics}

Interestingly, support was not found for providing instruction in a manner congruent with an individual's learning style. Specifically, when a task was less complex, there was no significant difference on performance or perceived mental effort between verbal and visual processors for either level of vividness. When the task was more complex, there was no significant difference on performance or perceived mental effort between visual and verbal processors in the less vivid condition; however, in the more vivid condition the visual processors performed better and perceived the task to require less mental effort than the verbal processors. It is interesting to note that even verbal processors performed better in the more- versus less-vivid condition and perceived the task to require less mental effort in the more- versus less-vivid condition.

These findings imply that the cognitive load associated with the more complex task could not be overcome by an individual's preference for processing alone in the less vivid condition. Furthermore, the results suggest that, regardless of learning style, media at tributes can be utilized to reduce cognitive load to a certain extent, at which point other mechanisms, such as designing the learning environment to meet the needs of different learning styles, can be employed to reduce cognitive load even further. 


\section{Limitations, Implications, and Future Research}

\section{Limitations}

A number of limitations must be considered when interpreting the results of this study. First, the generalizability of behavioral research may be called into question due to a reliance on student subjects. Second, the combined effects of vividness and interactivity were never explored. Third, no attempt was made to disentangle the relationships between the dependent variables.

\section{Theoretical and Practical Contributions}

In terms of theoretical contributions, this research helped to broaden the scope in which the TaskTechnology Fit model has been examined by applying the model to computer-mediated learning tasks. Furthermore, whereas prior studies utilizing the TTF model have, for the most part, measured perceived performance, the current study helps to further test the TTF model by measuring actual performance.

This research also contributed to our theoretical understanding of instructional design and the influence of technology characteristics, specifically vividness and interactivity. The results from this study imply that while technology characteristics have a direct impact on some learning outcomes, specifically satisfaction and interest, their impact on other outcomes, such as performance, vary depending on characteristics of thetask.

The findings also address a well-debated issue about the impact that an individual's learning style has on learning outcomes. In sum, the benefits of providing instruction in a manner consistent with an individual's particular learning style may only be realized if an individual's cognitive capacity has not been maxed out by characteristics of the task. The findings also indicate that designing a learning environment to accommodate varying learning styles may not overcome the amount of cognitive effort associated with certain tasks.

In terms of practical contributions, the results of this study will help to inform those who design and disseminate knowledge via technology, be it universities or organizations, of the influence that technology, task, and individual characteristics can have on the effectiveness of computermediated learning. Based on the findings, a computer-mediated learning environment can be customized around the type of information that is being disseminated and the targeted individual. This would greatly enhance the learning experience for the learner, as they may not haveto expend as much effort to learn something if it is delivered in a manner that is more conducive to learning.

\section{Future Research}

There are a number of opport unities in this area that merit further exploration. Fut ure studies should investigate not only more instances (i.e., levels) of each of these variables, especially vividness and interactivity, but also the effects that emerge as a result of combining different technology attributes. It may also be beneficial to investigate the long-term influence of the treatment conditions on learning as it has been noted that an important aspect of learning is retention of knowledge (Haseman et al., 2002). Another area of potential research is to examine the relationships between the various learning outcomes. It may be the case that the only true endogenous variable among the learning outcomes studied is performance, and that the other variables act to mediate the relationship between task, technology, and individual characteristics and performance. Finally, an opportunity for future research lies in examining the influence of other individual characteristics, such as prior knowledge and computer self-efficacy, on learning outcomes. 
Nicholson, Nicholson, \& Valacich

\section{Conclusion}

Today's knowledge economy has given rise to a dramat ic increase in the utilizat ion of technology as an educational tool with which to convey information to learners. How best to use this technology, however, has come under scrutiny. While it may be tempting to buy into the notion that a dazzling technology display is more effective, critics caution that technology should be a means to an end rather than an end in itself (Large, 1996). Perhaps the most realistic view of this situation is to realize that different media have different advantages and that the most efficient way for learning to occur is when strat egies are designed to suit characteristics of the task and the individual (Alavi \& Leidner, 2001, Goodhue et al., 2000; Steuer, 1992).

This study drew on the Task-Technology Fit Framework (Goodhue, 1995) in order to take a first step at investigat ing the influence of technology, task, and individual characteristics on learning outcomes. T wo technology characteristics identified in the literature as having an influence on learning through a computer-mediated environment are vividness and interactivity. While these characteristics were expected to have a direct relationship with some of the learning outcomes, it was also believed that their impact on other learning outcomes would be influenced by characteristics of the task and the individual. The current study specifically examined the influence of vividness, interactivity, task complexity, and learning style in the context of learning procedural knowledge.

Overall, results from the study support the proposed research model. Findings indicate that presenting information in a more vivid or more interactive learning environment will significantly increase both satisfaction with the learning environment as well as interest in the presentation topic. Furthermore, strong support was found for utilizing a more vivid or more interact ive presentation to increase performance and reduce perceived mental effort when a task is more complex. Finally, mixed support was found for the hypotheses regarding the influence of vividness and learning style on performance and perceived mental effort for a more complex task indicating that leaming style does not appear to have as great of an impact on leaming outcomes as prior research has suggested.

Overall, the relationships examined in this study made significant strides towards understanding the direct, as well as combined, influence of task, technology, and individual characteristics. The results from hypothesis test ing provide strong support for the proposed research model, and contribute both practically and theoretically to research on computer-mediated learning. Additionally, the current study provides a theoretically sound framework for fut ure research to investigate how, why, and under what conditions technology, task, and individual characteristics can be combined to design computer-mediated learning environments that enhance learning out comes.

\section{References}

Agius, H. W., \& Angelides, M. C. (1999). Developing knowledge-based intelligent multimedia tutoring systems using semantic content-based modeling. Artificial Intelligence Review, 13, 55-83.

Alavi, M. (1994). Computer-mediated collaborative learning: An empirical evaluation. MIS Quarterly, $18(2), 150-174$.

Alavi, M., \& Gallupe, R. B. (2003). Using information technology in learning: Case studies in business and management education programs. Academy of Management Learning and Education, 2(2), 139-153.

Alavi, M., \& Leidner, D. E. (2001). Research commentary: Technology-mediated learning: A call for greater depth and breadth of research. Information Systems Research, 12(1), 1-10.

Alavi, M., Wheeler, B., \& Valacich, J. (1995). Using IT to reengineer business education: An exploratory investigation of collaborative telelearning. MIS Quarterly, 19, 159-174. 
Alessi, S. M., \& Trollip, S. R. (1991). Computer-based instruction: Methods and development (2nd ed.). New Jersey: Prentice Hall.

Alessi, S. M., \& Trollip, S. R. (2001). Multimedia for learning: Methods and development. Needham Heights, MA: Allyn and Bacon.

Anderson, J. R. (2000). Cognitive psychology and its implications. New York, NY: Worth Publishers.

Andres, H. P. (2004). Multimedia, information complexity, and cognitive processing. Information Resources Management Journal, 17(1), 63-78.

Bannert, M. (2002). Managing cognitive load: Recent trends in cognitive load theory. Learning and Instruction, 12, 139-146.

Bersin \& Associates. (2007). The 2007 corporate learning factbook: Benchmarks, facts, and analysis in US corporate learning and development.

Bolt, M., Killough, L., \& Koh, H. (2001). Testing the interaction effects of task complexity in computer training using the social cognitive model. Decision Sciences, 32(1), 1-19.

Brown, J. S., Collins, A., \& Duguid, P. (1989). Situated cognition and the culture of learning. Educational Researcher, Jan-Feb, 32-42.

Campbell, D. J. (1988). Task complexity: A review and analysis. Academy of Management Review, 13(1), 40-52.

Chandler, P., \& Sweller, J. (1991). Cognitive load theory and the format of instruction. Cognition and Instruction, 8, 293-332.

Chen, J. Q., Lee, T. E., Zhang, R., \& Zhang, Y. J. (2003). Systems requirements for organizational learning. Communications of the ACM, 46(12), 73-78.

Childers, T. L., Houston, M. J., \& Heckler, S. E. (1985). Measurement of individual differences in visual versus verbal in formation processing. Journal of Consumer Research, 12(2), 125-134.

Clark, R. E. (1983). Reconsidering research on learning from media. Review of Educational Research, 53(4), 445-459.

D’Ambra, J., \& Rice, R. E. (2001). Emerging factors in user evaluation of the world wide web. Information and Management, 38, 373-384.

Davis, F. D., Bagozzi, R. P. \& Warshaw, P. R. (1992). Extrinsic and intrinsic motivation to use computers in the workplace. Journal of Applied Social Psychology, 22, 1111-1132.

Dillon, A. \& Gabbard, R. (1998). Hypermedia as an educational technology: A review of the quantitative research literature on learner compreh ension, control, and style. Review of Educational Research, $68(3), 322-349$.

Dishaw, M. T., \& Strong, D. M. (1999). Extending the technology acceptan ce model with task-technology fit constructs. Information and Management, 36, 9-21.

Doll, W. J., \& Torkzadeh, G. (1988). The measurement of end-user computing satisfaction. MIS Quarterly, $12(2), 259-274$.

Eveland, W. P., Jr. (2003). A 'mix of attributes' approach to the study of media effects and new communication technologies. Journal of Communication, 53, 395-410.

Frederiksen, J. R., White, B. Y., \& Gutwill, J. (1999). Dynamic mental models in learning science: The importance of constructing derivational linkages among models. Journal of Research in Science Teaching, 36(7), 806-836.

Furr, R. M., \& Rosenthal, R. (2003). Evaluating theories efficiently: The nuts and bolts of contrast analysis. Understanding Statistics, 2(1), 45-67.

Gagne, R. M., Briggs, L. J., \& Wager, W. W. (1992). Principles of instructional design. Belmont, CA: Wadsworth. 
Goodhue, D. L. (1995). Understanding user evaluations of in formation systems. Management Science, 41(12), 1827-1844.

Goodhue, D. L., Klein, B. D., \& March, S. T. (2000). User evaluations of IS as surrogates for objective perform ance. Information and Management, 38, 87-101.

Hagmann, S., Mayer, R. E., \& Nenniger, P. (1998). Using structural theory to make a word-processing manual more understandable. Learning and Instruction, 8(1), 19-35.

Haseman, W. D., Polatoglu, V., \& Ramamurthy, K. (2002). An empirical investigation of the influences of the degree of interactivity on user-outcomes in a multimedia environment. Information Resources Management Journal, 15(2), 31-48.

Heinich, R., Molenda, M., \& Russell, J. O. (1989). Instructional media and the new technologies of instruction (3rd ed.). New York: Macmillan Publishing Co.

Johnson-Laird, P. N. (1983). Mental models. Cambridge, MA: Harvard University Press.

Keller, J. M., \& Suzuki, K. (1988). Use of the ARCS motivation model in courseware design. In D.H. Jonassen (Ed.), Instructional designs for microcomputer courseware (pp. 401-434). Hillsdale, NJ: Lawrence Erlbaum.

Kettanurak, V., Ramamurthy, K., \& Haseman, W. D. (2001). User attitude as a mediator of learning perfo rmance improvement in an interactive multimedia environment: An empirical investigation of the degree of interactivity and learning styles. International Journal of Human-Computer Studies, 54, 541583.

Kinzie, M. B., Sullivan, H. J., \& Berdel, R. L. (1988). Learner control and achievement in science computer-assisted construction. Journal of Educational Psychology, 80(3), 299-303.

Kristof, R., \& Satran, A. (1995). Interactivity by design: Creating and communicating with new media. CA: Adobe Press.

Kozma, R. B. (1991). Learning with media. Review of Educational Research, 61(2), 179-211.

Large, A. (1996). Computer animation in an instructional environment. Library and Information Science Research, 18(1), 3-23.

Lawless, K. A., \& Brown, S. W. (1997). Multimedia learning environments: Issues of learner control and navigation. Instructional Science, 25, 117-131.

Leidner, D. E., \& Fuller, M. (1997). Improving student learning of conceptual in formation: GSS supported collaborative learning vs. individual constructive learning. Decision Support Systems, 20(2), 149-163.

Leidner, D. E., \& Jarvenpaa, S. L. (1993). The information age con fronts education: Case studies on electronic classrooms. Information Systems Research, 4, 24-54.

Lepper, M. (1985). Microcomputers in education: Motivational and social issues. American Psychologist, $40,1-18$.

Lim, K. H. (1996). Multimedia as an enabling technology for enhancing organizational memory to support decision making. Unpublished Ph.D. Dissertation, University of British Columbia.

Lim, K. H., \& Benbasat, I. (2002). The influence of multimedia on improving the comprehension of organizational information. Journal of Management Information Systems, 19(1), 99-127.

Lim, K. H., Benbasat, I., \& Ward, L.M. (2000). The role of multimedia in changing first impression bias. Information Systems Research, 11(2), 115-136.

Lim, K. H., O’ Connor, M. J., \& Remus, W. E. (2005). The impact of presentation media on decision making: Does multimedia improve the effectiveness of feedback? Information and Management, 42(2), 305.

McKellar, P. (1957). Imagination and thinking. New York: Basic Books. 
Merrill, M. D. (1975). Learner control: Beyond aptitude-treatment interactions. AV Communications Review, 23, 217-226.

Merrill, M. D. (1983). Component display theory. In C. M. Reigeluth (Ed.), Instructional design theories and models. Hillsdale, NJ: Erlbaum Associates.

Merrill, M. D. (1994). Instructional design theory. Englewood Cliffs, NJ: Educational Technology Publications.

Miller, G. A. (1979). Images, models, similes, and metaphors. In A. Ortony (Ed.), Metaphor and thought (pp. 202-250). London: Cambridge University Press.

Mitchell, M. (1993). Situational interest: Its multifaceted structure in the secondary school mathematics classroom. Journal of Educational Psychology, 85, 427-439.

Nicholson, J. (2006). Computer-mediated learning: An empirical examination of the influence of technology, task, and individual characteristics. Unpublished Ph.D. Dissertation, Washington State University.

Paas, F. (1992). Training strategies for attaining trans fer of problem-solving skill in statistics: A cognitiveload approach. Journal of Educational Psychology, 84(4), 429-434.

Paivio, A. (1971). Imagery and verbal processes. New York, NY: Holt, Rinehart, and Winston. (Reprinted 1979, Hillsdale, New Jersey: Erlbaum.)

Paivio, A. (1986). Mental representations: A dual-coding approach. New York: Oxford University Press.

Piccoli, G, Ahmad, R., \& Ives, B. (2001). Web-based virtual learning environments: A research framework and a preliminary assessment of effectiveness in basic IT skills training. MIS Quarterly, 25(4), 401426.

Pillay, H. (1998). An investigation of the effect of individual cognitive preferences on learning through computer-based instruction. Educational Psychology, 18(2), 171.

Rai, A., Lang, S. S., \& Welker, R. B. (2002). Assessing the validity of IS success models: An empirical test and theoretical analysis. Information Systems Research, 13(1), 50-69.

Rieber, L. P. (1994). Computers, graphics and learning. Madison, WI: Brown and Benchmark.

Renninger, K. A., Hidi, S., \& Krapp, A. (1992). The role of interest in learning and development. Hillsdale, NJ: Lawrence Erlbaum Associates.

Riding, R. J., \& Dyer, V. A. (1980). The relationship between extraversion and verbal-imag ery learning style in twelve-year-old children. Personality and Individual Differences, 1, 273-279.

Rosenthal, R., \& Rosenow, R. L. (1985). Contrast analysis: Focused comparisons in the analysis of variance. New York: Cambridge University Press.

Sadoski, M., \& Paivio, A. (2001). Imagery and text: A dual coding theory of reading and writing. Mahwah, NJ: Erlbaum Associates.

Shuell, T. (1986). Cognitive conceptions of learning. Review of Educational Research, 56(4), 411-436.

Sojka, J. Z., \& Giese, J. L. (2001). The influence of personality traits on the processing of visual and verbal inform ation. Marketing Letters, 12(1), 91-106.

Steuer, J. (1992). Defining virtual reality: Dimensions determining telepresence. Journal of Communication, 42(4), 73-93.

Sweller, J. (1988). Cognitive load during problem solving: Effects on learning. CognitiveScience, 12, 257285.

Sweller, J. (1989). Cognitive technology: Some procedures for facilitating learning and problem solving in mathematics and science. Journal of Educational Psychology, 81, 457-466. 
Sweller, J. (1994). Cognitive load theory, learning difficulty, and instructional design. Learning and Instruction, 4, 295-312.

Sweller, J., \& Chandler, P. (1994). Why some material is difficult to learn. Cognition and Instruction, $12(3), 185-233$.

Sweller, J., vanMerrienboer, J. J. G., \& Paas, F. G. W. C. (1998). Cognitive architecture and instructional design. Educational Psychology Review, 10, 251-296.

Syed, M. R. (2001). Diminishing the distance in distance education. IEEE Multimedia, July-Sept., 18-21.

Tan, J .K. H. \& Benbasat, I. (1990). Processing of graphical in formation: A decomposition of taxonomy to match data extraction tasks and graphical repres entations. Information Systems Research, 1(4), 416439.

Tractinsky, N., \& Meyer, N. (1999). Chartjunk or goldgraph? Effects of present ation objectives and content desirability on information presentation. MIS Quarterly, 23(3), 397-420.

Webster, J., \& Hackley, P. (1997). Teaching effectiven ess in technology-mediated distance learning. Academy of Management Journal, 40(6), 1282-1309.

White, B., \& Frederiksen, J. (1990). Causal model progressions as a foundation for intelligent learning environments. Artificial Intelligence, 42, 99-157.

Williams, M. D. (1996). Learner-control and instructional technologies. In D. H. Jonassen (Ed.), Handbook of research for educational communications and technology. Macmillan, NY: Simon and Schuster.

Wild, M. (1996). Mental models and computer modeling. Journal of Computer Assisted Learning, 12(1), 10-21.

Wilson, J. R., \& Rutherford, A. (1989). Mental models: Theory and application in human factors. Human Factors, 31(6), 617-634.

Wittrock, M. C. (1978). Developmental processes in learning from instruction. Journal of Genetic Psychology, 132, 37-54.

Wood, R. (1986). Task complexity: Definition of the construct. Organizational Behavior and Human Decision Processes, 37(1), 60-82.

Zazel enchuk, T.W. (1997). Interactivity in multimedia: Reconsidering our perspective. Canadian Journal of Educational Communication, 26(2), 75-86.

Zhang, D., \& Nunamaker, J. F. (2003). Powering e-learning in the new millennium: An overview of elearning and enabling technology. Information Systems Frontiers, 5(2), 207.

Zigurs, I., \& Buckland, B. K. (1998). A theory of task/technology fit and group support system effectiveness. MIS Quarterly, 22(3), 313-334.

\section{Biographies}

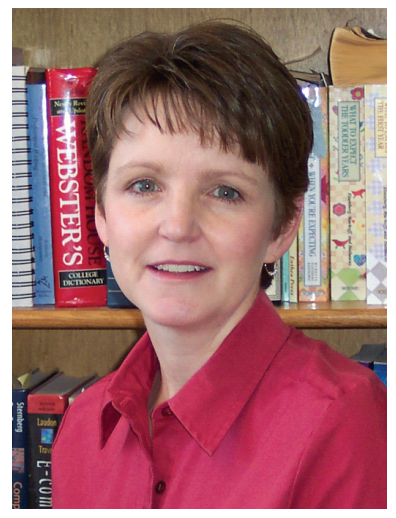

Jennifer A. Nichols on is an Assistant Professor in MIS at Rowan University. She received her Ph.D. in Business Administration, with a specialization in Information Systems from Washington State University. Her research interests include computer-mediated learning, human-computer interaction, and mobile technologies. She has published articles in Informing Science Journal, AMCIS proceedings, and HICSS proceedings. 




Darren B. Nicholson is an Assistant Professor in MIS at Rowan University. His research interests include virtual teams, human-computer interaction, e-business, and distance education. His research has been published in outlets such as IEEE Transactions on Professional Communication, Journal of Information Technology Theory and Application, AMCIS proceedings, and HICSS proceedings. His teaching interests include systems analysis and design, web development, and networking and telecommunications.

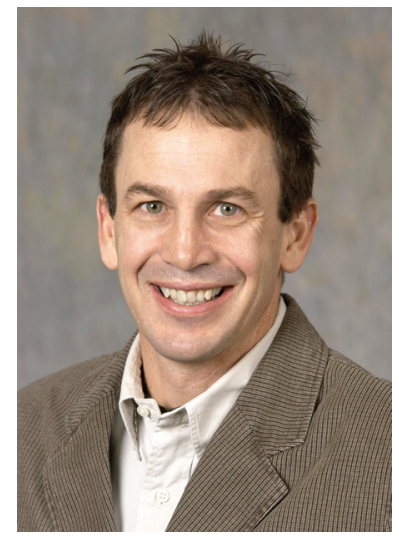

Jose ph S. Valacich is the Hubman Dist inguished Professor of MIS at Washingt on State University. His primary research interests include technology-mediated collaboration, human-computer interaction, mobile and emerging technologies, e-business, and distance education. $\mathrm{He}$ is a prolific researcher, with more than 70 journal publications in numerous prestigious journals including MIS Quarterly, Information Systems Research, Managem ent Science, Academy of Management Journal, Communications of the ACM, Decision Science, Journal of MIS, Journal of Applied Psychology, and many others. 